\title{
Economic, Social and Demographic Impact of Burmese Invasion of Manipur
}

Yaiphaba Ningthoujam ${ }^{\dagger}$

\section{Abstract}

Adversarial relationship best describes the history between the Kingdom of Manipur and Burma. As expected between neighbours, there had been frequent wars, alliance formation through intermarriages, trade ties and cultural exchanges. The watershed in the bilateral relationships was the Burmese occupation during 1819-1826; a period described as the 'Seven Years Devastation'. It was the last and the most destructive in the series of invasions that befalls the Kingdom of Manipur. Considered the darkest phase, the seven years left an indelible mark in the mindset of the Manipuris. The trail of destruction and devastation that the invading Burmese armies left in the psyche of the Manipuris are still retold in the popular folklore, ballads, and enacted in plays. It had left a penetrating impact on the social, economic, demographic, cultural and even foreign relations of Manipur.

Keywords: Manipur; Burma; War; Economy; Demography

\footnotetext{
${ }^{+}$Assistant Professor, Centre for Study of Social Exclusion \& Inclusive Policy, Manipur University, Manipur, India, Pin 795008, Email: yaipha_ning@yahoo.co.in

(C) 2021 Ningthoujam. This is an Open Access article distributed under the terms of the Creative Commons Attribution License (http://creativecommons.org/licenses/by/2.0), which permits unrestricted use, distribution, and reproduction in any medium, provided the original work is properly cited.
} 


\section{Introduction}

The Kingdom of Manipur and its relations with her eastern neighbour Burma was marked by adversariality and periodic intimacy. As expected among many neighbouring kingdoms in the world, the relationships have had phases of cordiality, cultural symbiosis, matrimonial alliances, and trade and commercial exchanges.

By making ample use of historiography, this discussion explores the gamut of economic, social and demographic impacts of the Burmese occupation of Manipur during1819-26. However, it is pertinent to mention that Manipur was not always at the receiving end of the intermittent wars and expeditions. Manipur kings also had a fair share of successful expeditions against the Burmese.

The postulations are that the invasion, apart from inflicting a short-term fatal blow to the very existence of the Manipuri Kingdom, brought about far-reaching repercussions that ultimately changed her destiny. The aftermath of the invasion led to the downfall of the might of both Manipur Kingdom and Burma, and drastic change in the region's geo-politics, thereby paving the way for the British Imperialism's open entry.

In substantiating the argument that follows, not only the Manipuri chronicles in vernacular are optimally used but also Burmese and British accounts to corroborate the facts. In the process, the study tries to unearth the seldom-discussed aspects of the impacts of the invasion on Manipur, which could be considered as a watershed in her long recorded history.

The paper is divided into the following. The first part introduces the whole study. Following this, it attempts to encapsulate the intermittent yet belligerant wars fought between Manipur and Burma until the first quarter of the 19th Century. It then provides an overview of the events leading to the ill-fated Burmese invasion of
Manipur in 1819 and its reasons. The next section accounts for the unwanted devastation of Manipur at the hands of the marauding Burmese during the course of their invasion. It is then followed by a section that analyses the demographic jolt resulting in the complete depopulation of Manipur on account of the devastation. It further chronicles the social changes brought about by the invasion and the economic destruction resulting from the massive defeat at the hands of the Burmese. The final section draws on the conclusion.

\section{Manipur and Burma: A History of Wars}

Manipur, once a princely State, is one of the eight northeastern states of India. It has a total geographical area of 22,327 Sq. Km of which $90 \%$ are the hill areas. The state has a $352 \mathrm{Km}$ long international boundary with Burma to the southwest while having a $502 \mathrm{Km}$ long boundary with other States of the Indian union, including Assam, Nagaland, and Mizoram. It has a population of about 3 million as per the census of 2011.

The state has a long recorded history starting from 33 A.D with the accession of King Pakhangba to the throne. Except for periodic occupations by the Burmese, Manipur remained an independent Kingdom until the British annexed her in 1891. The Royal Court Chronicle of Manipur, Cheitharol Kumpapa mentioned Manipur's encounters with the Pongs ${ }^{1}$ and Kapos $^{2}$ as early as 663 AD (Parratt, 2009). The Burmese, as well as the British historians like Harvey (2000) and Hall (1981) based on Burmese Chronicles clearly mentioned Manipur as being conquered by the Burmese during the reign of King Bayinuang (1551-81), though most Manipuri historians discounted these interpretations. In the 17th Century there were repeated invasions by the Aawas ${ }^{3}$ in 1648, 1651 and 1692. The rise of Manipur Kingdom's

\footnotetext{
${ }^{1}$ Former Shan state in upper Burma whose capital was Mogoung. It was annexed to Burma in 1752.( Dun,1981,p.188)

2 Or Kabaw. Now in Sagaing region of Burma.

3 The Burmese as known by the Meiteis. It is corrupted from Ava, the ancient capital of Burma.
} 
power ${ }^{4}$ in the first half of the 18th Century under Garibniwaz (1709-1748) ${ }^{5}$ turned the tide as he led to a series of successful expeditions against the Burmese. Yet, the Manipur King could not sustain its hold over Burma due to the Konbaung dynasty's rise under Alaungpaya (1752-60). Thereafter, the history of Manipur till the first quarter of the 19th Century was of repeated Burmese invasions, which at times completely devastated the Kingdom.

During her height of power under Garibniwaz, Manipur repeatedly invaded Burma first in 1725, followed in 1735, 1738, and 1739 ending ultimately in $1749 .{ }^{6}$ Under him, its expert horsemen became the terror of upper Burma (Hall, 1981). In fact, the lightning attack of cavalry was the main reason for the success of the Manipuris against the Burmese under Garibniwaz (Parratt, 1989). The repeated invasions of Burma under Garibniwaz gave a fatal blow, thereby contributing to the Toungoo dynasty's downfall (1510-1752). Following the abdication of the throne by Garibniwaz and coinciding with the rise of the Konbaung dynasty (1752-1885) in Burma under Alaungpaya led to the downfall of Manipuri might. Hence began the saga of a multitude of Burmese raids starting with 1755, which ultimately ended with the withdrawal of the Burmese in 1826. The country was invaded in 1755, followed in 1758 under Alaungpaya and then in 1764, 1769 and 1772, all under Sinbyuyin (1763-76). In all the mentioned years except for the first, the Cheitharol Kumpapa recorded the land being invaded and devastated by the Burmese. There were also reports of Burmese invasions under King Singu (1776-82), but they were not mentioned in Manipuri Chronicles.

\footnotetext{
${ }^{4}$ Manipur was an independent kingdom before her annexation by the British in 1891. After independence she merged to the Indian Union in 1949.

${ }^{5} \mathrm{As}$ recorded in Cheitharol Kumpapa, the royal court chronicle of Manipur. However, British authors like Pemberton, Dun and Harvey mentioned the year of the accession of Garibniwaz as 1714 . There is discrepancy as to when he abdicated the throne as well.

${ }^{6}$ Though Cheitharol Kumpapa mentioned that Garibniwaz abdicated his throne in the year 1748, it mentioned his presence in Burma as he planned to attack it in the year
}

The signing of the Treaty of Yandaboo ${ }^{7}$ in 1826 after the defeat of Burma in the First AngloBurmese War put an end to the series of calamitous Burmese invasion of Manipur. Before it, the Burmese invasions in Manipur were so frequent and devastating during the second half of the 18th Century to the beginning of the 19th Century that in the words of Harvey:

Thus, for sixty years, the Burmese would march to Manipur whenever the mood seized them, round up several hapless people, and re-enact the same terrible scenes as before. (Harvey, 2000, p.299)

\section{Seven Years Devastation (1819-26): The Prelude}

The Burmese invasion and consequent devastation of Manipur during 1819-26, also known as the seven years devastation, is the most severe and the last of the series of Burmese invasion and destruction that befall Manipur in her long written history. However, the Kingdom was not only the sufferer of the rise of the Burmese might at the beginning of the $19^{\text {th }}$ Century under its King Bagyidaw (1819-37). Assam, a neighbouring State, was also at the receiving end of the Burmese atrocities since it became its actual master in 1821 and continued to be so till 1825 (Baruah,1983). During those years under the Burmese, the Assamese suffered untold miseries like the Manipuris, which are still unforgotten as Manor Din.

Various reasons have been propounded for the causes of the Burmese invasion of Manipur by different historians. The refusal by King Marjit, who ruled Manipur as a vassal state ${ }^{8}$ of Burma from 1813-19, to attend the coronation of King Bagyidaw in 1819 was mentioned as the main

1749. The same account is supported by the British historians.

${ }^{7}$ It was signed between the Burmese and the British government on $24^{\text {th }}$ February 1826 thereby putting an end to the first Anglo- Burmese war (1824-26). According to the terms of the treaty, the Burmese recognised the independence of Manipur.

${ }^{8}$ After the Manipuri forces were defeated, Marjit was made the King of Manipur by the Burmese in 1813 after accepting their surzerainty along with ceding of Kabaw valley to Burma. 
reason for the Burmese attack. The cutting of a large quantity of timber by the Manipuris from the Kabaw valley despite the renunciation of all her rights therein by the king of Manipur, thereby offending Burman sumptuary law, was given by Spearman (1880) as another reason. King Marjit also offended the Burmese by building a gilded palace which was not allowed other than the Burmese King (Harvey, 2000).

Apart from the above factors, Sanajaoba (2005) put forward several other factors like feelings of economical insecurities and jealousy coupled with the revenge ethos of 'Letzya-Kya' on the Burmese part of the invasion. On the other hand, Manipuri historians like Birachandra (2009) and Indramani (2015) considered the frequent wars of succession among the descendants of Garibniwaz and internecine feuds among the Manipuri princes as one of the main reasons for the attack of the Burmese and her subsequent conquest. The fratricidal conflicts among the princes for the throne started after the death of King Bhagyachandra in 1799 , thereby creating a conducive atmosphere for the Burmese to invade Manipur in 1819. Marjit had to take the help of the Burmese to usurp the throne by expelling his brother King Chourjit Singh (1803-1813).

On a different note, Nimai (2020) was of the opinion that the Burmese invasion of Manipur was not an end in itself; rather, it was a means for her further expansion to Cachar ${ }^{9}$ valley and further to the Bay of Bengal. On the other hand Burmese scholar, Aung (1967) opined that the Manipuri attempt to please the mighty British power at the cost of ties with the Burmese for the last few decades angered the Burmese. On the fateful day, December 1, 1819, King Bagyidaw ordered to invade Manipur. Accordingly, to conquer Manipur, a Burmese force was despatched led by the great General Maha Bandula. Two columns were sent as a part of the Manipur campaign; one under Thado Min Ye Kyaw Zwa, which marched to Manipur via Su Bon route while the other column was led by Thado Min Ye Kyaw Htin from the Tammu route (Than,1988). A sanguinary battle followed at

\footnotetext{
${ }^{9}$ Now a district of present Assam state of India.
}

Kakching in the southern side of the Imphal valley, which lasted for eight days after which Marjit fled to Cachar along with his followers. In Cheitharol Kumpapa, it was written, Poinu ${ }^{10}$ the fifth Tuesday, the combat with the Aawas began and on twelfth Tuesday, the land was devastated. General Kane Woon and two thousand Burmese stayed behind to live and ravage the country. For seven years, the Burmese unleashed a reign of terror upon the hapless residents of the Kingdom, thereby making it the darkest period in the history of Manipur.

\section{The Reign of Terror}

The cruelties and atrocities of the Burmese in their conquered territories were well known as seen as well in Arakan and Assam (Kabui, 2003). The Burmese army's conduct in their conquests was brutal and dehumanising, and Manipur bore the maximum brunt of her invasions among the neighbours since the rise of Konbaung dynasty. The unsavoury military conduct in the conquered territories is vividly explained in the words of Crawfurd:

The conduct of the Burmans, in their predatory excursions, is cruel and ferocious to the last degree and scarcely any people of Asia have more greatly abused the right of conquest. They are not themselves unaware of the barbarous spirit in which theirs wars are conducted. (Crawfurd, 1834, p. 422)

The Burmese almost completely devastated the Manipur during the invasion of 1819-26. During the seven years, Manipur was completely annihilated and razed to the ground. Moreover, several thousands of her people were either maimed or executed, while several other thousands were dragged to Burma as prisoners of war (Sanajaoba,2005). The horrifying tales of Manipuris being herded like animals and killing them using biological weapons - gassing the populace with burnt chillies after locking them up in houses, are still sung as ballads by the elders. Up to this day, the annihilation method of the Burmese is in the lips of the Meitei elders

10 The month of November/ December. 
(Singh, 2005). The devastation that the invading Burmese forces brought upon the Manipuris is vividly described in the words of Kabui:

Manipur had never before experienced such a national catastrophe brought about by the Burmese conquest. The oppression and cruelties with which the Burmese dealt with the Manipuris had no parallel in the history of Manipur. It was a sort of genocide of the Meiteis that had been carried by the Burmese reign of terror. (Kabui, 2003, p.289)

The mass exodus, killing, and large deportation resulted in total desertion of Manipur, thereby reducing it into a cemetery. The wraths of Gods had befallen Manipur, thereby making the period, perhaps the saddest in her long history (Singh, 1963). For generations, the devastation left deep and inerasable imprints in the collective psyche of the Manipuris. The scars of the atrocities committed by the Burmese during those years still remains. In fact songs are still sung and stories narrated, remembering the terrors of those unforgettable years.

Pemberton (2015) considered Burmese conquests of Manipur were an attempt to extirpate the Manipuri race that they found it impossible to subdue permanently. Like any neighbouring countries of Burma, Manipur was to doom to the devastating Burmese invasions. The Kingdom was in fact devastated intermittently by the Burmese since the middle of the 19th Century. However, as Kamei (2015) has put it aptly, it could not destroy the Meitei nation. Sanajaoba (2005) considered the survival of Manipur after passing through successive Burmese invasions as not only enigmatic but also as an act of miracle. Though such terrible devastation came rarely in the history of a nation, the survival of Manipur in her fight against the Burmans may be considered as a remarkable one.

\section{The Demographic Slump}

Though Manipur had seen repeated Burmese ravages in the past, the scale of devastation of

\footnotetext{
11 The Meiteis as known by the Burmese.
}

1819-26 was unparalleled in her history. During this period, the Burmese nearly depopulated the country (McCulloch, 1980). Many Manipuris were killed, leaving behind nobody to mourn and perform their last rites (Singh, 1963). Unable to withstand the brutalities, Manipuris in thousands fled to neighbouring Assam and further to Tripura and Bangladesh. Many more took refuge amongst the hill people, and some of them in the marshes in the southern part of the valley of Manipur, where the Burmese could not reach (McCulloch, 1980).

The Burmese also carried away a large number of prisoners of war as captives. The Cheitharol Kumpapa mentioned that three hundred thousand Manipuris were taken as captives and carried away to Burma in 1819 and 1820 (Parratt, 2009). Consequently, it may be concluded that the Burmese carried away altogether 60,000 Manipuris as war captives during 1819 and 1820. Instances of the Meiteis being carried away to Burma as war captives happened in earlier invasions too. Manipur was considered in the past as a source of precious human resources for Burma (Kazumasa, 2014).

Before 1819, under King Alaungpaya also, thousands of Manipuri were deported to Burma and made them resettled. Inscriptions of King Sinbyuyin from the year 1767 mentioned the Burmese invasion in Manipur in 1763 and their return with 30,000 Kathes ${ }^{11}$ as prisoners of war (Forchhammer, 2015). However, in the Chietharol Kumpapa the year of the battle was mentioned as the year 1764 . The settled Meiteis in Burma served in different capacities as cavalry soldiers, boatmen, textile artisans, astrologers, domestic workers, etc. By the mid 19th Century, the Kathes formed nearly a quarter of the population of the capital $\mathrm{Ava}^{12}$ or at least 25,000 (Myint, 2001). They were also largely diffused in nearly all the districts of central Burma (Yule, 1858). Now, most of them have been fully Burmanised.

The mass exodus of the Meiteis, killings by the marauding Burmese armies and large scale deportation as war captives in thousands

\footnotetext{
12 The former capital of Burma.
} 
resulted in a serious demographic slump as never experienced in Manipur. Before the invasion, Johnstone (1896) estimated the total population of the valley of Manipur from 500 to 1,000 persons per sq. mile, which was about 4 , 00,000 to $6,00,000$ populations. So much was the scale of the demographic slump that after the Burmese's final withdrawal in 1826, the population of the valley was reduced to a few thousands.

Among the authors, there were some differences as to the number of people in the valley in the aftermath of the devastation. While Brown (2001) estimated the population at 3,000, Allen (2010) gave the opinion that the number of people did not exceed 8,000 souls. Kamei (2015) estimated the whole population after 1826 to be 10,000 while Jhonstone (1896) gave the lowest figure at just 2,000 souls. On the higher side, Pemberton (2015) was of the belief that the population in the valley must have been around 20,000 souls, which consisted of those escapes from Burma since the war, returned emigrants from the British provinces and those born after 1825. Thus, by any estimate, the population of the valley during and after the devastation was reduced to such an extent that when Gambhir Singh ascended the throne, he had to start everything from scratch. After Gambhir Singh's consolidation and reconstruction, the population rose to 40,000 after his death in 1834. Further, in 1859 it was estimated to have risen to 50,000, which further increased to 65,000 - 70,000 in 1868 as per McCulloch's calculation (Brown, 2001).

Yet another significant demographic impact of the devastation is the emergence of the huge imbalance of the Manipuri population between the two sexes (Singh, 2005). The reason is not surprising, considering that most of the killed and war captives taken away were men.

\section{Social Transformation}

The seven years of devastation, apart from giving a fatal blow to the economy and demographic structure, also hugely altered the social set up of

\footnotetext{
13 A dance performed in moonlight by the Meiteis during the festival of Holi.
}

Manipur in the 19th Century and thence. Those eventful years resulted in massive changes in the Kingdom's overall social, political, cultural and religious scenario. The demographic slump, as discussed earlier, resulted in certain changes in her social traditions, which are still in vogue. Foremost, it resulted in the tacit encouragement of the practice of polygamy and early marriage in accordance with the societal need to increase population (Birachandra, 2009). Earlier, the practice of polygamy was confined to the Kings and nobles and found to be very rare among the commons. It was practiced among the common people only under certain circumstances like when the women are issueless or have no son, wife becoming mentally or physically challenged or suffering from terrible diseases or indulging in immoral activities (Birachandra,1987). The massive depopulation also resulted in certain social traditions meant to encourage populations like the insertion of erotic songs in Lai Haraoba and encourage boys and girls' free mingling in Thabal Chongba ${ }^{13}$ (Singh, 2005).

Chaki- Sircar (1984) mentioned two distinct changes in women's sex roles in the aftermath of the seven years of devastation. Firstly, it enhanced the role of wife and husband-wife companionship in a monogamous union. Secondly, it enlarged the household of women with more opportunity and responsibility in subsistence because of the absence of a sufficient number of able-bodied males. The devastation of 1819-26 and the earlier devastations in the 18th Century led to the higher role of women of Manipur as the primary bread earner of the household besides occupying a pivotal position in the society. Singh (1972) reasoned that the high participation of women in the socio-economic life of Manipuri society is due to frequent wars within themselves and the common enemy, that is, Burma and consequent depopulation of the male population at their hand. Naturally, in the absence of a husband and all the able-bodied young men, houses had to be run by the womenfolk. 
The increasing contact with the British after the 1826 treaty also brought about far-reaching social impacts, which led to vast changes in the way of life of the Manipuris. In 1835, the British political agent was established in Manipur with Captain Gordon as the first political agent. The successive political agents ushered in the light of western education in Manipur. The introduction of western education acted as a catalyst of social change, altering existing outlook and belief and leading to the emergence of an elite group that wanted progress and modernisation (Goshwami, 2018). The transformation of the economic system after the contact with the British also brought about a sharp difference between the rich ruling elite and the poor common people (Ranjana, 2015).

The seven years of devastation also resulted in certain impacts on the religious sphere in Manipur as well. During those years, she lost many temples, monastics, scriptures, idols and shrines (Tejbanta, 2015). After the Burmese left, increased contact with the western people resulted in the coming of more Brahmins and the visit of Manipuris to holy places of Hindus (Ranjana, 2015). The successive Manipuri Kings also tried their best to revitalise the Hindu religion in Manipur.

\section{The Collapse of the Economy}

The Burmese invasion of $1819-26$ also gave a crushing blow to the overall economy of Manipur like never experienced before. The complete depopulation of the valley virtually led to a total collapse of all sectors of the economy from which it took many years to recover. The complete depopulation resulted in the destruction of agriculture, trade and commerce and construction works. Since all the villages in the valley were deserted, paddy fields were left fallow resulting in their outgrown with long grasses (Kamei, 2015). The contemporary official account mentioned the valley being covered up with dense jungles and swamps (Banerjee, 1946). During those years, as much of the fertile valley lands were left to fallow, agricultural production decreased drastically in the Kingdom.
Accounts given by Pemberton (2015) mentioned that the area under cultivation was scarcely onefourth of that was cultivated before the onslaught of the Burmese.

Since there were no harvest and hence no production during those seven years, frequent famines visited the country, taking a toll on many people's lives. Even the deaths could not be given proper cremation (Singh, 1965). The Cheitharol Kumpapa mentioned that in 1821 in the month of June/ July, there was a severe famine resulting in many people's death. The price of paddy in the month was $15,00,000$ sen $^{14}$ a sangbai ${ }^{15}$ basket. The increase in paddy price could be ascertained from the fact that it reduced to 5, 00,000 sen a sangbai basket in the next year.To bring down the price of paddy, it was procured from the hills and distributed to the starving subjects (Singh,1965).

The Burmese invasion also completely ruined the cottage industries of Manipur (Roy, 1973). The first blow to the country as a centre of artistic and industrial activity was also inflicted by repeated Burmese invasions, which captured nearly all the famous silversmiths of Manipur (Hodson, 1981). The Burmese also took away and settled a number of skilled artisans of silk, weavers, carpenters, painters, goldsmiths, rowers, indigenous physicians, etc. thereby destroying the overall industry that existed in Manipur (Bahadur, 2014). They also left a trail of physical destruction in the valley during their stay in Manipur. They plundered and destroyed whatever they came across by burning them to ashes (Birachandra, 2009). The Burmese also completely destroyed the houses of the villages in the valley, and even the walls of the Raja's palace were levelled with the ground (Brown, 2001).

To sum up, the entire infrastructure that existed was totally destroyed by the invading Burmese army, and the process of destruction and plunder continued unabated till they left the Kingdom. The physical destruction of the then existing structures was so complete that after the Burmese left the country, all of them were in 
a desolate state, and the capital Imphal exhibited few remnants of having been the capital of a Kingdom, and the only fragment remains were ruins of some brick temples of insignificant interest or extent (Wilson,1827). They also carried away any valuables, including cattle, clothes, utensils, foods. that they came across (Birachandra, 2009). Thus, the Burmese invasion struck a fatal blow to the overall economy of Manipur during those seven long years from which Manipur took many years to recuperate.

\section{Conclusion}

The Burmese invasion of $1819-26$ is considered the darkest phase in the history of Manipur. Its pervasive impacts were widespread, which felt on the demography, economy, society, polity, culture and even foreign relations. The invasion and the resulting annihilation were considered an attempt on the Burmese to permanently subdue a race that they found it challenging to subjugate in the past. However, the seven years of the reign of terror could not break down the indomitable spirit and nationalism of the Manipuris; she sprang back up from the ashes like the proverbial phoenix after the Burmese left in 1826. The British's close association in the fight against the Burmese ultimately led to her eventual association with the British and an era of colonial rule after 1891 . Thus, the Burmese invasion of 1819-26, apart from making devastating short term effects, resulted in a more eventual long term impact whereby Manipur was drawn closer to British imperialism. From different perspectives, the ill-fated seven years is still considered an epoch-making event in modern Manipur's history.

\section{References}

Allen, B.C. (2010). Gazetteer of Naga Hills and Manipur. New Delhi: Mittal Publications. (Original Work Published 1905).

Aung, M. H. (1967). A history of Burma. New York \& London: Columbia University Press.

Bahadur, M. (2014). Awa: Kate and Paona. Imphal: Mutua Museum.
Banerjee, A.C. (1946). The eastern frontier of British India (1784-1826). Calcutta: A. Mukherjee \& Bros.

Baruah, S.L.(1983). The Burmese and the north east : From the middle of the $18^{\text {th }}$ century to the treaty of Yandabo in 1826. Proceedings of the Indian History Congress, Vol . 44.(609613).https://www.jstor.org/stable/44139912.

Birachandra, N. (1987). Socio religious life of the Meiteis in the $18^{\text {th }}$ century A.D.(Unpublished $\mathrm{Ph}$. D. thesis). Manipur University, Canchipur, Imphal.

Birachandra, N. (2009). Seven years' devastation (1819-26). Imphal: P.S. Publications.

Brown, R. (2001). Statistical account of Manipur. New Delhi: Mittal Publication. (Original Work Published 1874).

Chaki-Sircar, M. (1984). Feminism in a traditional society: Women of the Manipuri valley. Delhi: Shakti Books.

Crawfurd, J. (1834). Journal of an embassy from the governor general of India to the court of Ava. Second Edition, Vol. 1. Dublin: Henry Colburn.

Dun, E.W. (1981). Gazetteer of Manipur. Delhi: Vivek Publishing Company. (Original Work Published 1886).

Forchhammer, E. (2015). Inscriptions of Pagan, Pinya and Ava. Rangoon: Andesite Press. (Original Work Published 1899).

Goshwami, H. (2018, February 21). Phases of Manipuri culture: A historical perspective. Imphal Times. Retrieved from https://www.imphaltimes.com/itarticles/item/10711-phases-of-manipur-culturea-historical-perspective/amp.

Hall, D.G.E. (1981). A history of South East Asia ( $4^{\text {th }}$ Ed.). London: Palgrave Macmillan. (Original Work Published 1955).

Harvey, G.E. (2000). History of Burma. New Delhi: AES Reprint( Original Work Published 1925). 
Hodson, T.C. (1981). The Meithies ( $2^{\text {nd }}$ Repeat Ed.). Delhi: B.R. Publishing Corporation. (Original Work Published 1908).

Indramani, N. (2015). The socio-cultural and historical accounts of Manipur. Imphal: N.I. Publications.

Johnstone, J. (1896). My experiences in Manipur and the Naga hills. London: S. Low, Marston and Company Ltd.

Kabui, G. (2003) History of Manipur. Vol.1. Precolonial period. New Delhi: National Publishing House.

Kamei, G. (2015). A history of modern Manipur (1826- 2000). New Delhi: Akansha Publishing House.

Kazumasa, I. (2014). The foreign presence in Mandalay during the Konbaung period: $A$ review of the urban area. The Journal of Sophia Asia Studies, 32,113-128.

McCulloch, W. (1980). Valley of Manipur. Delhi: Gyan Publications (Original Work Published 1859).

Myint, U. T. (2001). The making of modern Burma. United Kingdom: Cambridge University Press.

Nimai, R.K. (2020, January 8). A view on two wars fought in Manipur. Imphal Free Press. Retrieved from https://ifp.co.in/a-view-on-twowars-fought-in-manipur/.

Parratt, S.N.(1989). Garib Niwaz : Wars and religious policy in $18^{\text {th }}$ Century Manipur. Internationales Asienforum, 20 (3-4), 295-302.

Parratt, S.N.A. (2009). The court chronicle of the kings of Manipur: The chietharol kumpapa, Vol. 2, 1764-1843 CE. New Delhi: Cambridge University Press.

Parratt, S.N.A. (2019). The court chronicle of the kings of Manipur: The chietharol kumpapa, Vol.1, 33-1763. Imphal: Jain Book Shop Publication.

Pemberton, R.B. (2015). The eastern frontier of India. New Delhi: Mittal Publications (Original Work Published 1835).
Ranjana, M. (2015).Meitei women in the $19^{\text {th }}$ century Manipuri society. In Sudhir, H., S. B. Singh \& N. J. Singh (Eds.), Proceedings of The Manipuri Historical Society, $8^{\text {th }}$ Session (117128). Imphal: Rinda Publications.

Roy, J. (1973). History of Manipur. Imphal: (n. p.)

Sanajoaba, N. (2005). Ed. Manipur: Past and present. Vol.4. New Delhi: Mittal Publications.

Singh, M. J. (1963). Bejoy punchalee. Imphal(n .p.)

Singh, M.K. (2005). Status of Meiteis in Myanmar. In Sanajoaba N. (Ed.), Manipur: Past and present. Vol.4 (95-105). New Delhi:Mittal Publications.

Singh, N. T. (1972). Manipur: A study. Imphal: Raj Stores.

Singh, R.K. J. (1965). A short history of Manipur. Imphal: O.K. Store.

Spearman, H.R. (1880). The British Burma gazetteer. Vol. 1. Rangoon: Government Press.

Tejbanta, S. (2015). Politics of religion: A study from Bhagyachandra to Chandracriti. In Sudhir, H., S. B. Singh \& N. J. Singh (Eds.), Proceedings of The Manipuri Historical Society, $8^{\text {th }}$ Session (174-185). Imphal:Rinda Publications.

Than, T. (1988). The royal orders of Burma, A.D. 1598-1885. Retrieved from https:/repository.kulib.kyotou.ac.jp>dspace>bitstream.

Wilson, H. H. (1827). Ed., Documents illustrative of the Burmese war. Calcutta: Government Gazette Press by G.H. Huttmann.

Yule, H. (1858). Narrative of the mission sent by the governor-general of India to the court of Ava in 1855. London: Smith, Elder \& Co.

\section{Conflict of Interest}

I have no conflict of interest

\section{Acknowledgements}

I am incredibly grateful to the anonymous referee as well as the copyeditor for their valuable suggestions. 